\title{
Assessment of Natural Radionuclide Content of Common Brands of Cement Used in Nigeria
}

\author{
R. K. Meindinyo, E. Agbalagba, S. A. Olali* \\ Department of Physics, Niger Delta University Wilberforce Island, Amassoma, Bayelsa State, Nigeria./ *Isaac \\ Jasper Boro College of Education, Sagbama, Bayelsa State, Nigeria*
}

\begin{abstract}
The gamma spectrometric analysis of different brands of cement consumed in Nigeria has been carried out in this study. Samples of 12 brands of grey Ordinary Portland Cement (OPC) and 5 brands of white cement of six samples each were collected and analysed for their radiological content using gamma spectrometry method. The average value of ${ }^{226} \mathrm{Ra},{ }^{232} \mathrm{Th}$, and ${ }^{40} \mathrm{~K}$ for OPC is $30.2 \pm 1.0 .4 \mathrm{Bqkg}{ }^{-1}, 24.6 \pm 7.1 \mathrm{Bqkg} \mathrm{g}^{-1}$, and $251.3 \pm 27.6 \mathrm{Bqkg}^{-1}$ respectively and the average value for the white cement is $41.9 \pm 16.7 \mathrm{Bqkg}^{-1}$, $30.1 \pm 9.4 B q \mathrm{~kg}^{-1}$ and $340.2+77 \mathrm{Bqkg}{ }^{-1}$ respectively. The total average content of ${ }^{226} \mathrm{Ra},{ }^{232} \mathrm{Th}$, and ${ }^{40} \mathrm{~K}$ for all the cement brand samples are $36.1 \pm 13.6 \mathrm{Bqkg}^{-1}, 27.4 \pm 8.3 \mathrm{Bqkg}^{-1}$, and $295.8 \pm 32.7 \mathrm{Bqkg}{ }^{-1}$ respectively. These values obtained are lower when compared to the world average values (50, 50 and $500 \mathrm{Bqkg}^{-1}$ ) for building materials. The estimated radium equivalent activities (Raeq), representative index (I $\gamma)$, average absorbed $\gamma$-dose rate $(D)$, the annual effective dose rate (AEDE), annual gonadal dose equivalent (AGDE) external and internal hazard indices and the Excess life cancer risk (ELCR) were lower than the recommended safe limit and are comparable with results from similar studies conducted in other countries. The evaluated mean gonadal dose equivalents of three cement brand samples were fund to be higher than the world average for building material while others are less than the world average.
\end{abstract}

Keywords: natural radioactivity, gamma spectroscopy, cement, Nigeria

\section{Introduction}

Gamma radiation from radionuclides which is characterised by long half-life comparable to the age of the earth, this represents the main sources of external irradiation to the human body. Man and the biota are continuously irradiated by this ionizing radiation from many sources broadly classified as either natural or artificial. Most of the total radiation exposure of man and his environment come from natural sources (UNSCEAR, 2000). This natural radiation comes from two main sources: cosmogenic radionuclides $\left({ }^{3} \mathrm{H},{ }^{14} \mathrm{C}\right.$ etc) and long lived primordial radionuclide and their daughters $\left({ }^{40} \mathrm{~K},{ }^{238} \mathrm{U},{ }^{235} \mathrm{U}\right.$, and ${ }^{232} \mathrm{Th}$ ). The amount of the cosmogenic radionuclides is basically constant because of equilibrium between their rate of creation by cosmic radiation and their radioactive decay (Mikhail, 2008). Although the amount of primordial radionuclide keeps decreasing slowly with time due to radioactive decay, quite a significant amount still remain in the earth crust today due to their long half lives. These natural (primordial) radionuclides are known to be distributed in rocks and soil across the earth in varying concentrations depending on the geography and geological formations. Higher radiation levels are associated with igneous rocks, such as granite and phosphate, whereas, lower levels with sedimentary rocks.

The inhomogeneous distribution of these radionuclides in geological formations like soils and rocks suggests that man made products derived from these substances will contain traces of these radioisotopes whose concentrations will be dictated by the origin of the soil and rocks they are derived from one of such materials derived from rocks in Portland cement. Portland cement is a major building material used worldwide; it is derived from mixing natural clay, limestone and gypsum at high temperature (Kpeglo, et al., 2011). Cement when mixed with fine and coarse aggregate in the right proportion is used for making concrete block - a basic building material worldwide.

The use of cement as a basic building and construction material cuts across all social and economic strata in Nigeria. It is used (when mixed with other materials such as fine and) majorly in making concretes, sand blocks and for floors, walls, bridges and even roof finishing. A random survey on the application of cements in building revealed that over $90 \%$ of structures used as homes, offices, and commercial centres in Nigerian urban areas are constructed majorly using cement as binding material for concrete blocks (Sam and Abbas, 2001). In rural areas where clay/mud blocks and other locally sourced materials are used, it is common to see walls and floors plastered using cement paste. Consequently, Nigeria yearly consumption of cement stood at 10 million tons (Farai and Eje, 2006), and has been on the increase due to rapid structural and infrastructural development by government $t$ at all levels and the rapid increase in population and the consequent need for more homes and public structures. About two decades ago, a large proportion of cements used in Nigeria are imported (Esubiyi, 1995) while lesser proportion comes from the local industries. Today, the number of local cement 
industries has swollen such that more than $70 \%$ of locally consumed cement is manufactured locally. Generally, the local producing companies are located in areas where the raw materials are obtained while the imported product comes majorly from Asian and European countries. Although the brand names of some of the cements may suggest that they are manufactured in Nigeria, research has shown that some local companies only package imported cement dust using different brand names (Avwiri, 2005). The diverse sources of these cements imply that their natural radionuclide content will vary. Many research conducted and completed all over the world (Esubiyi, 1995; El-Bahi, 2004; Khalid and Hasan, 2001; etc.), has shown that natural radionuclids is present in Portland cement in varying concentration from country to country. Due to the diverse application of cement in building constructions, it could account for the bulk of indoor background radiation exposure to the populace. Furthermore, the grain size of cement is such that it is aerodynamic (Esubiyi, 1995), which could easily pass through respiratory track, or get blown by air into food and water. Consequently, the presence of radionuclide in cement does not only pose potential external radiation hazard but could also cause internal radiological contamination as well.

Many works have been done in Nigeria on building materials including cements without indication of brand name and their acceptability and covering the entire country. Thus, one is not sure about the nature and the distribution of the cement referred to in those works. In this study, the natural distribution of the cement brands considered is emphasised using the Nigeria map for the first time. Furthermore, this work considered brands that make up of more than $96 \%$ of those presently used in Nigeria including those used as tiles adhesive. This work would serve as indicator of the indoor and outdoor radiation exposure of Nigerian people due to cement.

In the light of the diverse application of cement in Nigeria building construction industries and the fact that an average Nigerian spends about $870 \%$ of their time indoors, the knowledge of radiological content and associated hazard from cement is thus a necessity. The aim of this study is therefore to quantify the natural radionuclide content of cements available in local market in Nigeria and estimate he potential radiological hazard to the dwellers of buildings constructed from such cements. The data from this study may be used by Nigerian authority for the development and implementation of radiation protection guidelines for the use and management of cements in the country. The data in this work could also assist builders in Nigeria in considering radiological factor when making choices for cements rather than the traditional factors of cost and availability. Moreso, the data obtained in this study will add to the world data base of radioactivity content in cement as a building construction material.

\subsection{Sample Collection}

\section{Materials And Methods}

In order to collect cement brand samples that represent a fair proportion of major cement brands used in Nigeria, a survey was carried out. The survey includes visiting major cement factory, re-bagging site, suppliers' stores and sites where buildings were under construction throughout the six geopolitical zones in Nigeria. The survey revealed that the acceptability of a particular brand of cement is dictated by it availability and cost. The availability of a particular brand in a region is closely related to the proximity to the manufacturer or distributor and the cost of all local packaged cement brands are almost the same. The survey revealed that 12 grey cements and 5 white cements use as tile adhesive are generally used in different parts of Nigeria. The colour of each of the brands is given in Table 1. The cement brands and the places in Nigeria where they are mostly used are show in Fig. 1. Six samples of each brand of the 17 brands totalling 102 samples were collected from major suppliers, factories, re-bagging site and building/road construction sites. The samples were collected into clean plastic containers, sealed, marked and transported to the laboratory.

\subsection{Gamma spectrometry}

The samples of cements collected from construction site and major distributors and factories in location across the country where they are mostly found were collected for radioactivity measurement. Each sample was air dried and pulverised into powered form. $200 \mathrm{~g}$ of each powdered sample was put in a cylindrical polystyrene container and sealed with tapes to prevent radon permeability and left for more than four weeks in order to allow for radon and its short live progeny to reach radioactive equilibrium. After this period, the radioactivity measurement was carried out for $7 \mathrm{~h}$ using a $7.6 \mathrm{~cm} \times 7.6 \mathrm{~cm} \mathrm{NaI}$ (TI) detector with a resolution of $8 \%$ at $662 \mathrm{keV}$ and housed in $10 \mathrm{~cm}$ thick lead shield to reduce background gamma radiation. The power supply and the data acquisition of the energy spectra were achieved by using an integrated spectroscopy system from Bicron. The system utilised SAMPO S100 software package from Canberra. The energy calibration of the detector was performed using IAEA standard point sources $\left({ }^{109} \mathrm{Cd},{ }^{57} \mathrm{Co},{ }^{137} \mathrm{Cs},{ }^{54} \mathrm{Mn}\right.$, and ${ }^{22} \mathrm{Na}$ ) of gamma energy range between $83 \mathrm{keV}$ and $1275 \mathrm{keV}$ being the energy range of the radionuclide to be identified. To stimulate the cement samples, $200 \mathrm{~g}$ of IAEA-375 reference soil was used. The radioactivity concentrations of ${ }^{226} \mathrm{Ra}$ were determined from the photopeaks of $609.32 \mathrm{keV}\left({ }^{214} \mathrm{Bi}\right), 1120.20 \mathrm{keV}\left({ }^{214} \mathrm{Bi}\right)$ and $352.6 \mathrm{keV}\left({ }^{214} \mathrm{~Pb}\right)$ and that of 
${ }^{232} \mathrm{Th}$ from $969.3 \mathrm{keV}\left({ }^{228} \mathrm{Ac}\right)$ and $583.78 \mathrm{keV}\left({ }^{208} \mathrm{Tl}\right)$ while the radioactivity of ${ }^{40} \mathrm{~K}$ was determined from 1460.3 $\mathrm{keV}$ photopeak following the decay of ${ }^{40} \mathrm{~K}$.

\subsection{Radionuclide concentrations}

\section{Results And Discussion}

The measured activity concentration of ${ }^{226} \mathrm{Ra},{ }^{232} \mathrm{Th}$, and ${ }^{40} \mathrm{~K}$ in the various brands of cement considered in this work is given in Table 1 . From the table the mean activity concentrations varied generally from $23.3 \pm 9.6 \mathrm{Bqkg}^{-1}$ to $49.5 \pm 14.7 \mathrm{Bqkg}^{-1}$, from $18.1 \pm 5.6 \mathrm{Bqkg}^{-1}$ to $32.8 \pm 10.4 \mathrm{Bqkg}^{-1}$, and from $205.9 \pm 24.3 \mathrm{Bqkg}^{-}$ ${ }^{1}$ to $452.9 \pm 43.5 \mathrm{Bqkg}^{-1}$ for $226 \mathrm{Ra}, 232 \mathrm{Th}$, and $40 \mathrm{~K}^{-}$respectively. The mean concentrations of the grey ordinary Portland cement (OPC) brands varied from $23.3 \pm 9.6 \mathrm{Bqkg}^{-1}$ to $44.7 \pm 12.5 \mathrm{Bqkg}^{-1}$, from $18.1 \pm 5.6 \mathrm{Bqkg}^{-1}$ to $32.5 \pm 11.0 \mathrm{Bqkg}^{-1}$ and from $205.9 \pm 24.3 \mathrm{Bqkg}^{-1}$ to $401.9 \pm 38.1 \mathrm{Bqkg}^{-1}$ for ${ }^{226} \mathrm{Ra},{ }^{232} \mathrm{Th}$, and ${ }^{40} \mathrm{~K}$ respectively. While the mean concentrations of the white cement used as tile adhesive varies from $35.5+11.0 \mathrm{Bqkg}^{-1}$ to $49.5+14.7 \mathrm{Bqkg}^{-1}$, from $27.4 \pm 9.5 \mathrm{Bqkg}^{-1}$ to $32.8 \pm 10.4 \mathrm{Bqkg}^{-1}$, and from $283.8 \pm 35.6 \mathrm{Bqkg}^{-1}$ to $452.9 \pm 43.5 \mathrm{Bqkg}^{-1}$ for ${ }^{226} \mathrm{Ra},{ }^{232} \mathrm{Th}$, and ${ }^{40} \mathrm{~K}$ respectively. The mean concentrations of the radionuclides in OPC brands were found to be low when compared with those of white cements. The variation of the mean activity concentrations of the cement brands could be attributed to the variations in the geological origin of the raw material used in their production. All the white cement brands considered in this work were imported while only Burham and Bua are imported OPC. From the result it can be concluded that imported white cements in Nigeria tend to have higher activity concentrations when compared with the local OPC brands.Generally, the mean activity concentration of ${ }^{40} \mathrm{~K}$ in the natural environment (IAEA, 2003). The range of radionuclide concentrations in the cement brands were found to be below world average of $50 \mathrm{Bqkg}^{-1}, 50 \mathrm{Bqkg}^{-1}$ and $500 \mathrm{Bqkg}^{-1}$ for ${ }^{226} \mathrm{Ra},{ }^{232} \mathrm{Th}$, and ${ }^{40} \mathrm{~K}$ respectively in building materials (UNSCEAR, 1993), while the upper limits of the range was found to be higher than the world average of $35 \mathrm{Bqkg}^{-1}, 30 \mathrm{Bqkg}^{-1}$ and $400 \mathrm{Bqkg}^{-1}$ for ${ }^{226} \mathrm{Ra},{ }^{232} \mathrm{Th}$, and ${ }^{40} \mathrm{~K}$ respectively in soil (UNSCEAR, 2000).

\subsection{Radium equivalent activity}

Radium equivalent activity is single quantity that combines the radiological effects of ${ }^{226} \mathrm{Ra},{ }^{232} \mathrm{Th}$, and ${ }^{40} \mathrm{~K}$ in material used for buildings (Beretka and Mathew, 1985; Roy et al., 2000; Sam and Abbas, 2001). It is a weighted sum of activity concentrations of ${ }^{226} \mathrm{Ra},{ }^{232} \mathrm{Th}$, and ${ }^{40} \mathrm{~K}$ based on the assumption that $370 \mathrm{Bqkg}^{-1}$ of ${ }^{226} \mathrm{Ra}, 259 \mathrm{Bqkg}^{-1}$ of ${ }^{232} \mathrm{Th}$, and $4810 \mathrm{Bqkg}^{-1}$ of ${ }^{40} \mathrm{~K}$ produce the same gamma radiation dose rates (Dieb et al., 2008). The radium equivalent is calculated $R a_{e q}=C_{R a}+1.43 C_{T h}+0.077 C_{K}$

where $C_{R a}, C_{T h}$ and $C_{K}$ are the activity concentration of ${ }^{226} \mathrm{Ra},{ }^{232} \mathrm{Th}$, and ${ }^{40} \mathrm{~K}$ respectively. Any material whose radium equivalent activity concentration exceeds $370 \mathrm{Bqkg}^{-1}$ is not recommended for safe use as building material (Sam and Abbas, 2001). The evaluated $R a_{e q}$ for the cement is given in Table 2. For the grey cement, the mean $R a_{e q}$ varies from $66.6 \pm 19.3 \mathrm{Bqkg}^{-1}$ to $113.1 \pm 29.8 \mathrm{Bqkg}^{-1}$, while for the white cement it varies from $101.5 \pm 27.9 \mathrm{Bqkg}^{-1}$ to $125.5 \pm 32.8 \mathrm{Bqkg}^{-1}$.Generally, the $R a_{e q}$ for all the cement brands considered are less than the limit, $370 \mathrm{Bqkg}^{-1}$. A comparison of the mean radium equivalent activities in this work and those obtained from recent published work from other countries is given in Table 3. The variation in the $R a_{e q}$ from other countries can be attributed to the difference in the Geology and consequent geochemical constituent of the rock from which the cements were derived.

\subsection{Internal and external gamma indices}

Other indices used for testing the suitability of any material for safe use as building material are the external hazard $\left(\mathrm{H}_{\mathrm{ex}}\right)$ and internal hazard $\left(\mathrm{H}_{\mathrm{in}}\right)$ indices which are defined according to (Zarie and Al-Mugren, 2010) as:

$H_{\text {ex }}=C_{R a} / 370+C_{T h} / 259+C_{K} / 4810$

$H_{\text {in }}=C_{R a} / 185+C_{T h} / 259+C_{K} / 4810$

where $C_{R a}, C_{T h}$ and $C_{K}$ are the activity concentration of ${ }^{226} \mathrm{Ra},{ }^{232} \mathrm{Th}$, and ${ }^{40} \mathrm{~K}$ respectively. The activity limits in terms of thee limits is 1 for safe use of the material in building construction.

The external gamma indices for all the cements considered in this work are less than unity. The obtained values of the external hazard index for all the samples are given in Table 2. It varies from 0.21 for Sokoto cement locally produced, to 0.34 for magen roi, imported white cement. The internal hazard index $\left(H_{\text {in }}\right)$ quantifies the internal exposure to carcinogenic radon and its short lived progeny. The values of the calculated $H_{\text {in }}$ for the various brand of cement are also given in table 2, and are all less than 1 .

\subsection{Annual gonadal dose equivalent (AGDE)}

Since the gonads are considered as the organs of interest, together within the active bone marrow and bone surface cell, the annual gonadal dose equivalent (AGDE, $\mu \mathrm{Svy}^{-1}$ ) due to the specific activities of ${ }^{226} \mathrm{Ra}$, ${ }^{232} \mathrm{Th}$, and ${ }^{40} \mathrm{~K}$ was calculated by (Al-Jundi et al., 2006): 
$A G D E=3.09 C_{R a}+4.18 C_{T h}+0.314 C_{K}$

According to this model, a house is considered as a cavity with infinitely thick walls which makes it possible to make comparison of AGDEs of a house whose materials contains concentrations of ${ }^{226} \mathrm{Ra},{ }^{232} \mathrm{Th}$, and ${ }^{40} \mathrm{~K}$ with that of the world average of 35,30 , and $400 \mathrm{Bqkg}^{-1}$ respectively in soil (UNSCEAR, 2000). The implication of this is that, if a building has materials whose radioactivity of the three primordial radionuclides is lower than that of the world average, such building could act as a radiation shield for the inhabitant who AGDE would then be greater than the world average of $359.2 \mu \mathrm{Svy}^{-1}$ in soil. The mean AGDE of the OPC varies from $239 \mu \mathrm{Svy}^{-1}$ to $377.6 \mu \mathrm{Svy}^{-1}$ with a mean of $311 \mu \mathrm{Svy}^{-1}$. Of all the 9 OPC only Burham and Bua has AGDE greater than the world average value. For the white cements the AGDE varies from $329.8 \mu \mathrm{Svy}^{-1}$ to $414.8 \mu \mathrm{Svy}^{-1}$ with JK and Magen roi having AGDE values greater than the world average.

Table 1: Specific activities concentration of various Nigerian Portland and White cement brands

\begin{tabular}{|c|c|c|c|c|c|c|c|c|c|}
\hline \multirow{2}{*}{$\begin{array}{l}\text { Cement } \\
\text { Brand }\end{array}$} & \multirow{2}{*}{$\begin{array}{l}\text { Sample } \\
\text { Size }\end{array}$} & \multirow{2}{*}{$\begin{array}{l}\text { Cement } \\
\text { Colour }\end{array}$} & \multicolumn{2}{|c|}{${ }^{226} \mathrm{Ra}\left(\mathrm{Bqkg}^{-1}\right)$} & \multicolumn{2}{|c|}{${ }^{232} \mathrm{Th}\left(\mathrm{Bqkg}^{-1}\right)$} & \multicolumn{2}{|l|}{${ }^{40} \mathrm{~K}\left(\mathrm{Bqkg}^{-1}\right)$} & \multirow{2}{*}{$\begin{array}{l}\text { Raeq (Bqkg } \\
\left.{ }^{1}\right)\end{array}$} \\
\hline & & & Range & Mean & Range & Mean & Range & Mean & \\
\hline Ashaka & 6 & Gray & $19.1-26.7$ & $23.3 \pm 9.6$ & $17.3-23.0$ & $20.7 \pm 6.9$ & $216.0-233.4$ & $227.1 \pm 30.6$ & $70.4 \pm 21.8$ \\
\hline Atlas & 6 & Gray & $28.4-44.2$ & $39.5 \pm 16.4$ & $15.6-21.1$ & $19.4 \pm 8.3$ & $250.2-261.3$ & $254.8 \pm 32.3$ & $86.9 \pm 28.9$ \\
\hline Bua & 6 & Gray & $42.0-50.2$ & $44.7 \pm 12.5$ & $29.0-35.6$ & $32.5 \pm 11.0$ & $266.1-282.2$ & $275 . \pm 27.7$ & $112.4 \pm 30.4$ \\
\hline Burham & 6 & Gray & $33.3-42.5$ & $38.5 \pm 11.7$ & $26.2-34.1$ & $30.5 \pm 10.6$ & $389.0-421.9$ & $401.9 \pm 38.1$ & $113.1 \pm 29.8$ \\
\hline $\begin{array}{l}\text { Dangote } \\
\text { (Obajana) }\end{array}$ & 6 & Gray & $18.6-24.2$ & $22.6 \pm 6.7$ & $13.5-18.6$ & $19.3 \pm 7.1$ & $208.1-215.5$ & $211.1 \pm 28.3$ & $66.6 \pm 19.3$ \\
\hline $\begin{array}{l}\text { Dangote } \\
\text { (Ibese) }\end{array}$ & 6 & Gray & 20.8 & $25.6 \pm 6.3$ & 0.6 & 5.6 & .0 & 5.2 & 67 \\
\hline Eagle & 6 & & $29.8-35.4$ & $31.1 \pm 8.4$ & $22.6-29.4$ & $26.0 \pm 9.0$ & $209.5-217.3$ & $213.4 \pm 27.9$ & $84.7 \pm 23.4$ \\
\hline Elephant & 6 & Gray & $21.1-34.1$ & $28.8 \pm 7.2$ & $18.6-24.2$ & $20.1 \pm 8.6$ & $212.6-220.1$ & $217.1 \pm 27.6$ & $74.3 \pm 21.6$ \\
\hline Ibeto & 6 & $\mathrm{G}_{1}$ & $32.9-40.7$ & $36.4 \pm 11.6$ & $23.9-30.4$ & $27.4 \pm 9.0$ & $281.1-298.8$ & $289.4 \pm 34.4$ & $97.9 \pm 27.1$ \\
\hline Madewell & 6 & $\mathrm{G}_{1}$ & $36.4-43.3$ & $38.9 \pm 12.3$ & $21.3-34.6$ & $29.3 \pm 9.8$ & $211.8-222.1$ & $217.6 \pm 29.1$ & $97.6 \pm 28.6$ \\
\hline Sokoto & 6 & $\mathrm{G}_{1}$ & $25.5-30.3$ & $26.6 \pm 7.9$ & $17.0-24.2$ & $21.3 \pm 7.8$ & $198.2-209.8$ & $205.9 \pm 24.3$ & $72.9 \pm 20.9$ \\
\hline Unicem & 6 & Gray & $39.4-46.0$ & $43.3 \pm 13.4$ & $26.2-33.7$ & $30.1 \pm 9.4$ & $288.4-297.5$ & $293.7 \pm 34.0$ & $109.0 \pm 29.5$ \\
\hline \multicolumn{3}{|c|}{ Sub Average of Gray Cement } & $18.6-50.2$ & $30.2 \pm 10.4$ & $13.5-35.6$ & $24.6 \pm 7.4$ & $198.2-421.9$ & $251.3 \pm 27.6$ & 84.7 \\
\hline ABS & 6 & White & $37.1-42.8$ & $40.2 \pm 12.9$ & $22.2-30.4$ & $27.4 \pm 9.5$ & $301.2-324.9$ & $318.6 \pm 36.9$ & $103.9 \pm 29.3$ \\
\hline JK & 6 & White & $46.3-51.8$ & $49.5 \pm 14.7$ & $24.9-34.1$ & $29.6 \pm 8.2$ & $339.5-349.0$ & $342.4 \pm 37.8$ & $118.2 \pm 29.3$ \\
\hline Mag & 6 & $\mathrm{Wh}$ & $45.6-47.2$ & $46.7 \pm 14.6$ & $26.0-34.3$ & $30.7 \pm 8.8$ & $440.4-463.9$ & $452.9 \pm 43.5$ & $125.5 \pm 32.8$ \\
\hline Mou & 6 & $\mathrm{Wr}$ & 34 & $37.5 \pm 10.9$ & $28.2-35.1$ & $32.8 \pm 10.4$ & $277.1-285.5$ & $283.8 \pm 35.6$ & $106.3 \pm 28.5$ \\
\hline Rak white & 6 & White & $31.5-38.4$ & $35.5 \pm 11.3$ & $24.6-32.1$ & $29.8 \pm 9.7$ & $294.2-308.0$ & $303.5 \pm 34.8$ & $101.5 \pm 27.9$ \\
\hline \multicolumn{3}{|c|}{ Sub Average of White Cement } & $31.5-51.8$ & $41.9 \pm 16.7$ & $22.2-35.1$ & $30.1 \pm 9.4$ & $301.2-463.9$ & $340.2-37.7$ & 111. \\
\hline Average & 106 & & $18.6-51.8$ & $36.1 \pm 13.6$ & $13.5-35.6$ & $27.4 \pm 8.3$ & $198.2-463.9$ & $295.8 \pm 32.7$ & $98.1 \pm 28.0$ \\
\hline
\end{tabular}

Table 2: Estimated Radiation Hazard Indices of Nigerian Cement

\begin{tabular}{|c|c|c|c|c|c|c|c|c|c|c|}
\hline \multirow[t]{2}{*}{$\mathrm{S} / \mathrm{N}$} & \multirow[t]{2}{*}{ Cement Brand } & \multirow[t]{2}{*}{$\begin{array}{l}\text { Cement } \\
\text { Origin }\end{array}$} & \multirow[t]{2}{*}{ I $\gamma\left(\mathrm{Bqkg}^{-1}\right)$} & \multirow[t]{2}{*}{$\mathrm{D}\left(\eta \mathrm{G} y \cdot \mathrm{h}^{-1}\right)$} & \multirow[t]{2}{*}{$\begin{array}{l}\text { AEDE } \\
\left(\mathrm{mSvy}^{-1}\right)\end{array}$} & \multirow[t]{2}{*}{$\begin{array}{l}\text { AGDE } \\
\left.(\mathrm{mSvy})^{-1}\right)\end{array}$} & \multicolumn{2}{|c|}{$\begin{array}{l}\text { Hazard } \\
\text { Index }\end{array}$} & \multirow[t]{2}{*}{$\begin{array}{ll}E L C R & X \\
10^{-3} & \end{array}$} & \multirow[t]{2}{*}{$\begin{array}{l}\text { Raeq(Bqkg } \\
\text { 1) }\end{array}$} \\
\hline & & & & & & & $\mathrm{H}_{\mathrm{xx}}$ & $\mathrm{H}_{\text {in }}$ & & \\
\hline 1. & Ashaka & Nigerian & 0.5 & 33.1 & 0.04 & 0.17 & 0.19 & 0.25 & 0.14 & $70.4 \pm 21.8$ \\
\hline 2. & Atlas & Nigerian & 0.6 & 40.9 & 0.05 & 0.28 & 0.23 & 0.34 & 0.18 & $86.9 \pm 28.9$ \\
\hline 3. & Bua & Imported & 0.8 & 52.3 & 0.06 & 0.36 & 0.30 & 0.42 & 0.21 & $112.4 \pm 30.4$ \\
\hline 4. & Burham & Imported & 0.8 & 53.5 & 0.07 & 0.37 & 0.28 & 0.41 & 0.25 & $113.1 \pm 29.8$ \\
\hline 5. & $\begin{array}{l}\text { Dangote } \\
\text { (Obajana) }\end{array}$ & Nigerian & 0.5 & 31.2 & 0.04 & 0.22 & 0.18 & 0.27 & 0.14 & $66.6 \pm 19.3$ \\
\hline 6. & Dangote (These) & Nigerian & 0.5 & 31.7 & 0.04 & 0.22 & 0.18 & 0.25 & 0.14 & $67.5 \pm 16.2$ \\
\hline 7. & Eagle & Nigerian & 0.6 & 39.4 & 0.05 & 0.27 & 0.23 & 0.31 & 0.18 & $84.7 \pm 23.4$ \\
\hline 8. & Elephant & Nigerian & 0.5 & 34.8 & 0.04 & 0.24 & 0.20 & 0.28 & 0.14 & $74.3 \pm 21.6$ \\
\hline 9. & Ibeto & Nigerian & 0.7 & 45.9 & 0.06 & 0.32 & 0.26 & 0.36 & 0.21 & $97.9 \pm 27.1$ \\
\hline 10. & Madewell & Nigerian & 0.6 & 45.2 & 0.06 & 0.24 & 0.26 & 0.36 & 0.21 & $97.6 \pm 28.6$ \\
\hline 11. & Sokoto & Nigerian & 0.5 & 34.1 & 0.04 & 0.24 & 0.20 & 0.27 & 0.14 & $72.9 \pm 20.9$ \\
\hline 12. & Unicem & Nigerian & 0.8 & 50.9 & 0.06 & 0.35 & 0.29 & 0.41 & 0.21 & $109.0 \pm 29.5$ \\
\hline 13. & ABS & Imported & 0.8 & 48.9 & 0.06 & 0.34 & 0.28 & 0.39 & 0.21 & $103.9 \pm 29.3$ \\
\hline 14. & JK & Imported & 0.9 & 55.5 & 0.07 & 0.38 & 0.32 & 0.45 & 0.25 & $118.2 \pm 29.3$ \\
\hline 15. & Maggen roi & Imported & 0.9 & 59.5 & 0.07 & 0.42 & 0.34 & 0.47 & 0.25 & $125.5 \pm 32.8$ \\
\hline 16. & Moulders & Imported & 0.8 & 49.5 & 0.06 & 0.31 & 0.29 & 0.39 & 0.21 & $106.3+28.5$ \\
\hline 17. & Rak white & Imported & 0.7 & 47.5 & 0.06 & 0.33 & 0.27 & 0.37 & 0.21 & $101.5 \pm 27.9$ \\
\hline \multicolumn{3}{|c|}{$\begin{array}{l}\text { Average } \\
\text { World Standard }\end{array}$} & $\begin{array}{l}0.7 \\
\leq 1.0\end{array}$ & $\begin{array}{l}45.1 \\
\{60(18-93)\}\end{array}$ & $\begin{array}{l}0.06 \\
1.0\end{array}$ & $\begin{array}{l}0.31 \\
0.36\end{array}$ & $\begin{array}{l}0.26 \\
\leq 1.0\end{array}$ & $\begin{array}{l}0.36 \\
\leq 1.0\end{array}$ & $\begin{array}{l}0.21 \\
0.29\end{array}$ & $\begin{array}{l}98.9 \pm 32.6 \\
370.0\end{array}$ \\
\hline
\end{tabular}


Table 3: Comparison of mean radium equivalent $\mathrm{Ra}_{\mathrm{eq}}\left(\mathrm{Bqkg}^{-1}\right)$ in Nigeria brands of cements with reported values in others countries of the world

\begin{tabular}{|l|l|l|}
\hline Country & $\mathrm{Ra}_{\mathrm{eq}}\left(\mathrm{Bqkg}^{-1}\right)$ & References \\
\hline Ghana & 90.1 & [Kpeglo et al., 2011] \\
\hline Malasia & 188 & [Ibrahim, 1999] \\
\hline Zambia & 79 & [Hayambu et al., 1995] \\
\hline South Korea & 80.8 & [Lee et al., 2001] \\
\hline China & 127.7 & [Xinwei, 2004] \\
\hline Greece & 221.6 & [Papaefthymiou et al., 2008] \\
\hline India & 580.1 & [Sonkawade et al., 2008] \\
\hline Egypt & 291.9 & [Ahmed, 2005] \\
\hline Lebanon & 93.8 & [Kobeissi et al., 2008] \\
\hline Turkey & 246.1 & [Baykara et al., 2011] \\
\hline Nigeria & 96.4 & Present work \\
\hline
\end{tabular}

Table 4: Specific Activities and Colour of various Nigerian Portland Cement Brands

\begin{tabular}{|l|l|l|l|l|}
\hline Cement brand & Colour & ${ }^{226} \mathrm{Ra}$ & ${ }^{232} \mathrm{Th}$ & ${ }^{40} \mathrm{~K}$ \\
\hline Dangote & Grey & $33.9 \pm 16.2$ & $32.5 \pm 12.4$ & $289.7 \pm 79.3$ \\
\hline ABS & White & $40.2 \pm 13.9$ & $27.4 \pm 9.82$ & $324.9 \pm 63.9$ \\
\hline Burham & Grey & $39.5 \pm 18.7$ & $29.5 \pm 11.6$ & $421.9 \pm 89.1$ \\
\hline Rak white & White & $35.5 \pm 17.3$ & $29.8 \pm 9.7$ & $304.1 \pm 69.9$ \\
\hline Moulder3 & White & $35.5 \pm 17.3$ & $32.8 \pm 21.8$ & $283.8 \pm 65.6$ \\
\hline JK & White & $49.5 \pm 19.7$ & $28.4 \pm 11.2$ & $346.3 \pm 53.8$ \\
\hline Maggen roi & White & $46.7 \pm 14.6$ & $30.7 \pm 8.8$ & $452.9 \pm 55.5$ \\
\hline Unicem & Grey & $43.3 \pm 15.4$ & $30.1 \pm 9.9$ & $297.5 \pm 52.8$ \\
\hline Sokoto & Grey & $28.8 \pm 9.9$ & $22.3 \pm 8.8$ & $205.9 \pm 47.6$ \\
\hline Eagle & Grey & $31.1 \pm 11.4$ & $26.0 \pm 10.0$ & $212.7 \pm 57.9$ \\
\hline Ashaka & Grey & $24.9 \pm 10.3$ & $21.8 \pm 8.9$ & $227.1 \pm 39.7$ \\
\hline Ibeto & Grey & $37.2 \pm 12.7$ & $27.4 \pm 9.8$ & $298.8 \pm 48.5$ \\
\hline Bua & Grey & $46.3 \pm 12.5$ & $32.5 \pm 13.0$ & $295.8 \pm 27.7$ \\
\hline Atlas & Grey & $39.5 \pm 16.6$ & $19.4 \pm 8.3$ & $254.8 \pm 68.3$ \\
\hline Elephant & Grey & & & \\
\hline Madewell & Grey & & & \\
\hline
\end{tabular}

\section{Conclusion}

The natural radionuclide content and their consequent radiation hazard indices were evaluated in grey and white cement used in Nigeria. Although the mean specific activities of imported cement brands are higher than the locally produced ones, their total mean activities were less than the world average in building materials. The radium equivalent activities obtained for all the cement brands considered in this work were all below the criterion limit of radiation dose $(1.5 \mathrm{mSv} / \mathrm{y})$. Calculations of both internal and external gamma indices showed that no sample exceeded the recommended exemption levels of unity.

\section{Acknowledgement}

The authors are grateful to the Research and Technical Staff of Centre for Energy Research and Development (CERD), Ile-Ife, Nigeria for their assistance and for the use of gamma spectrometry equipment in their laboratory. We also appreciate all the anonymous reviewers whose suggestions have shaped this article to its present form.

[1]. Unscear,(2002): Effect and Sources of ionizing radiation.

\section{Reference}

[2]. Unscear,(2002): The United Nations Scientific Committee on the effects of Atomic Radiation.

[3]. Farai, I.P and Ejeh, J.E.(2006); Radioactivity concentrations in Common Brands of Cement in Nigeria.

[4]. D.O.Kpeglo, (2011): Gamma Spectrometric analysis of different brands of cement Used in Nigeria. Avwiri,(2003).

[5]. Sam and Abbas, (2007): Assessment of carcinogenic and Non-carcinogenic, Risk Lead in Bottled water in different Age Groups. Kobeissi etal, (2008).

[6]. Esubiyi, (1995): Radioactivity concentrations in common brands of cement in Nigeria-Cambridge University Press. Khalid and Hasan, (2007).

[7]. Ibrahim, (1999): The effect of bradyrhizobium inoculation on yield and seed Quality of guar.

[8]. Hayambu et al, (1995): Assessment of natural radioactivity and radiation doses-Shodhganga.

[9]. Lee et al, (2007): Regulation of a cyclin - CDK-CDK inhibitor complex by Insositol.Dieb et al, (2008). Zarie and Almugrem,(2010).

[10]. Xinwei, (2004): Natural radioactivity in some building materials and by products Of shaanxi, china / spring or link. Roy et al, (2000): Radio and optical variability.

[11]. Papaefthymion et al, (2008): Designing and characterization of Fe (111) complexes Of oxydiacetate containing a - diimine. Baykara et al,(2001). IAEA,(2003).Beretka and Mathew, (1985).

[12]. Gupta M, Chauhan RP.Estimation of low-level radiation dose from somebuilding Materials using HPGe gamma-ray spectrometry.Radiat prot dosim. 
[13]. Erees FS, Dayanikli SA, Cam S. Natural Radionuclides in the building materials used in manisa city, turkey.

[14]. Ben BS, Arunima S, Pereira CE, Sunil A, Jose RM. Natural radionuclides in Cements and clay based building materials used in south west coastal region Of india.Asian J phy Sci. (2012).

[15]. Righi S, Bruzzi L. Natural radioactivity and radon exhalation in building materials Used in Italian dwellings. J Environ Radioact. (2006).

[16]. USGS Fact Sheet FS-163-97.Radioactive Elements in Coal and Fly Ash.Abundance, forms, and Environmental significance, October, (1997). 